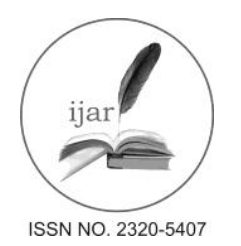

Journal homepage: http://www.journalijar.com

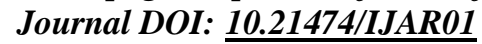

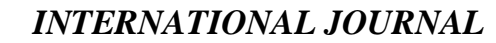

OF ADVANCED RESEARCH

RESEARCH ARTICLE

\title{
SOME ASPECTS OF THE CLAIM ON PROTECTION OF PROPERTY OWNERSHIP RIGHT.
}

\author{
Hamidjon Voxidov.
}

Independent researcher of the Tashkent State University of Law, Uzbekistan.

\section{Manuscript Info}

Manuscript History:

Received: 25 April 2016

Final Accepted: 19 May 2016

Published Online: June 2016

Key words:

Claim, Ownership, Property, Civil

Law.

*Corresponding Author

Hamidjon Voxidov.

\section{Abstract}

The issues of the claim on property ownership right are researched in the article. Theoretical analyze of the issues claim to work out several recommendations on enhancement of the sphere.

\section{Introduction:-}

The right of ownership is protected by several legal spheres (criminal, administrative, civil law). In the criminal law set a criminal punishment for grabbing of another's property, in the administrative law - administrative responsibility for offences against property of person.

Among mentioned before law spheres, undoubtedly, norms of constitutional law have distinctive point.

In particular, according to the article 53 of the Constitution of the Republic of Uzbekistan, the basis of the economy of Uzbekistan, which is directed to the development of market reforms, is composed the property various forms.

The state guarantees the freedom of economic activity, entrepreneurship and labor with considering of the priority of consumers' rights, equality and legal protection of all forms of ownership. Private property, along with the other types of property, is inviolable and protected by the state. An owner may be deprived of property, solely in the cases and procedure stipulated by law [1].

In the civil law it is explained the demand from the person, who violated the right of ownership, compensation of material and moral damage.

The term of claim is not used on regard to the requirements of proprietor or another owner on the prevention any offence referring to his/her rights, including the offences, which are not connected to ownership of property.

It is caused by that, this relations included to the circle of subjects of civil law. It is evident that, ownership relations are one of the regulated subjects of civil law.

However, in the circumstances it is explained a protection of material rights of owner - the right of ownership and usage.

\section{Methodology:-}

During the research analyzing, critical thinking, induction and deduction methods are used. 


\section{Observations:-}

In protecting the ownership rights, civil law norms perform different objectives. Some civil law norms define legally belonging of objects to certain persons (for instance, civil law norms about appearance and abolition of the right of ownership), the second group of rules provides the necessary conditions for the implementation concerning the rights of the owner, the third group norms performs the problem of protection of property rights directly from the influence of third parties. This civil law includes rules governing liability for material damage.

Moreover, there are special rules in civil law, aimed to civil law protection of the right of ownership. Therefore, in the civil law concepts of "protection of property relations" and the "protection of property relations" explained differently.

From our point of view, the concept of "protection of property rights" is wider than the concept of "protection of property relations". V.Y.Ergashev, stopping on the difference between these concepts, noted the following: "Civillaw protection of property rights is carried out by means of civil law, to ensure the normal and unimpeded development of these relations".

Civil defense - a relatively narrow concept against civil law protection, applies only in case of violation of property rights. Civil law protection of property rights - is a complex of civil legal methods, used to restore the broken relationships, which are a result of the commission of offenses concerning property relations. Thus, the protection of property rights is an integral part of the concept of civil rights, have a broader meaning than in civil law" [2].

Violation of the property rights by the third parties on the nature and substance of the proposed protection, in civil law the legitimate rights and interests of the owner are protected by a variety of civil-legal methods. A.P.Sergeev allocates these methods into the following groups:

- material-legal;

- obligatory;

- not related to the material-legal and obligatory methods, but arising from the various institutions of civil law;

- the abolition of property rights under statutory grounds, methods designed to protect the interests of the owner[3].

It would not be wrong to say that these methods in a broad meaning cover almost all rights in accordance to property.

If the right of ownership is violated and the property withdrew from the possession of the owner, the right of ownership is considered as an impaired: the owner generally can not exercise his/her right. Moreover, the violation of the right to use, though not violated the right of ownership, will interfere with the right of ownership. Therefore two types of claims - vindication and negatory are provided, they protect the right of ownership and use (vindication claim or vindication comes from the Latin word "vindicare", meaning "require", "protect").

Vindication claim is used in the illicit seizure of property from the actual the owner, provides a reclamation by the owner of unlawful possession of his/her property from another person.

Consequently, vindication claim is a requirement, given on the prevention of offense to any person, impeding the implementation of the rights of the owner to possess, use and dispose of property.

Who can apply with the vindication claim? Firstly, the owner of the property has such a right, the property (subject to the right of vindication). However, not only the owner, the other person according to the law, a person owning, the other person exercising the right of economic or operational control, can handle with this claim.

The object of vindication always considered as a personal subject, having the shape of nature.

When suing for the protection of property rights, a person illegally possessed the property, deemed responsible. If the defendant is not owner of the property, in accordance to it is not possible to deal with the claim vindication, because there is no subject of vindication. However, it may require from the person who owns the property illegally, the damage caused to the owner. The claim is given to the person, who is currently illegal owner of the property, it does not matter how he turned out to be out of property.

If there are abovementioned conditions, the owner can claim their property directly from the offender. Here is a vivid example of complexity of the question in the circumstances. For instance, in the spouses in a divorce, the husband without the wife's consent is selling the car, which is the common property. The claim of the former wife 
on the returning the car the new owner of the machine rejects, as he bought a car and spent money on its repair. In this regard, whose interests are important: the owner or the buyer face?

In answering this question, it should be remembered that there are two kinds of unlawful possession of another's property in the civil legislation, which lead to different legal consequences. Illegally possessing face divided into honest and dishonest owner. If the property purchased by charging the person has no right to transfer it to another person, if the recipient knew and could know it if property is lost by the owner or the person to whom the owner has given for possession or to steal from the owner or the person who gave the property, or withdrawn from their possession by others, regardless of their desires, then such owner is considered to be dishonest owner.

In this situation, the true owner of the property has the right to demand his property. At the same time, the honest owner can demand their money from the seller. If the vendor is not known, it is difficult to protect the rights of honest owner. If the property is acquired without payment from a person who has no right to transfer it to another person, the owner is also entitled to demand ownership in all situations.

Based on the mentioned above, we can conclude that in the case of filing of the claim to an honest owner in a situation related to the violation of a property right only in the following two circumstances, property can be seized:

Firstly, if the property is acquired without payment of cost (on a deed of gift, inheritance). Since this property exemption does not lead to any consequences to property, however, is the restoration of the violated property rights;

Secondly, if the property is purchased by a private owner by the board, and if the owner of the property loss method is important.

If the property is acquired by the board, the situation in which the property can not be claimed by the owner of an honest? If the property came from the ownership at the request of the owner. For example, a citizen out a long-term business trip their precious items left neighbor after neighbor's death, his heirs, not knowing the owner of the data items, sell them. While heirs and point to the person (the owner is honest), has bought items, the rightful owner can not return them because of their own accord handed over these items to own another person.

Requesting the legal owner of the property, it also has the right to demand the following:

- return or refund from the person (dishonest owner) knows of the illegality of their possession or which should have been aware of this, all income received or should have received the person for the time of possession of the property; - All income from a private owner since the knowledge of the unlawful possession or from the time in which he was supposed to know about it either since the admission requirements for the recovery of the claim of the owner of the property.

In turn, the owner of an honest and dishonest owner, as in the necessity of returning to the owner of the income received for the time of the property, and the right to demand compensation from the owner of the property expenses for the same period of time.

If the items that improve the thing can be separated without causing damage to things, then the owner has the right to a fair to keep the data subjects. If you can not separate such items, then an honest owner has the right to request charges made to improve things, but these costs should not exceed the value added to the subject.

With regard to the claim vindication not applicable claim periods. But there are three circumstances in which after a certain period of legal owner loses the right to property:

The first fact - finding. If during the period of six months from the time reported finding no face is detected, which is entitled to take the find the person who found a thing receives possession of the (CC, Article 192);

The second circumstance (similar to the first) - homeless animals. At the same time a basis different from dishonest possession vindication. Unsupervised or stray cattle or other neglected domestic or tamed animal is obliged to return them to the owner, and if the owner of the animals or his whereabouts are unknown, not later than three days after the arrest announced the discovery of animals to the police, the relevant public authority or the governing body of citizens who take measures to find the owner. 
If the person does not report which found, then it is dishonest owner (CC, Article 195);

The third factor - the restriction of vindication requirements in the time frame (a period during which there is the right of possession). After the expiration of that period the former owner loses the right and vindication in respect of their property (Civil Code, Article 187).

According to article 231 of the Civil Code, the owner may demand the elimination of all violations of his rights, although these violations were not connected with deprivation of possession (negatory lawsuit). According to I.B.Zokirov requirements of owners abuse their rights to own and use property (although it is not connected with the deprivation of the right of ownership) called negatory claims. The subject of the lawsuit is to require the owner of the property on the prevention of such offence[4]. According to V.Y.Ergashev, for presentation by the owner with a violation of the right negatory action requires a number of conditions, namely:

Firstly, preventing the actions of third parties of implementation of the owner of the right of use and disposal; Secondly, the illegality of such actions of third parties;

Thirdly, the continuing of illegal actions of third parties at the time of filing the negatory claim or eliminate the consequences of such actions. In this regard, in relation to the claims of the data in accordance with Article 163 of the Civil Code is not applicable claim periods.

Finally, it is required to the subject of ownership rights keep the property in his/her possession [5].

Subject of the negatory action, according to the Article 231 of the Civil Code, is the requirement of the plaintiff on the prevention of any offense not related to deprivation of the right to ownership.

Violation of rights as a result of actions of third parties causing a certain degree of damage to the owner. Therefore, the owner, along with the requirement of preventing any violations in the use of the property and can claim compensation for damage caused as a result of the offense. Although this requirement is connected with negatory claim ownership, but does not refer to its subject matter is the subject of a claim for damages. In this situation, for the submission of a claim for compensation for the damage caused to the owner S.V.Skryabin the need to confirm the existence of the damage and identify the causal relationship between the actions of third parties and damage to property[6].

Due to the fact that by negatory action in most cases claimed the removal action, preventing the use of the property, some authors believe that this claim leads to the factors hindering the use of only the owner of the property[7]. However, it is noteworthy that Article 231 of the Civil Code it is a question of any violation of property rights, not connected with deprivation of the right of ownership. Therefore, with the help of negatory action protects not only the owner of the right to use the property, but also the right to dispose of them.

For instance, next to the garage where your car is, any organization dug wide and deep ditch for laying pipes. You can not take the car out of the garage and use it. The fact that the organization had not violated your rights of ownership, did not took out the car. However, the violation of the right to use, you appear difficult. In this situation, the garage owner can go to a court with the requirement to eliminate the circumstances preventing the right to use the vehicle.

Subject of the negatory claim is the owner or another person, the owner. Subject of liabilities (the defendant in the suit) is the person, performing illegal actions violating the rights of the owner (usually this concerns the right to use, not related to the ownership and disposition, leads to difficulties with respect to real estate). If obstacles arise through the legal action, for example, if the pipes are laid in the prescribed manner and at the same time is not violated a person's right to own, and there are only some inconvenience (dust, sounds, etc.), or should they turn a blind eye, or need to make a complaint to the competent authorities on the extent of their legitimacy.

Object of the negatory claim is to prevent offences, continuing until the time of making the claim. Therefore, claim periods are not applicable for such a lawsuit. The requirement of such content may be given at any time of the action of the offense. After the completion of the offender illegal actions in court can be brought claim only on compensation for the damage. 
It is noteworthy that the theory and the judicial practice of modern civil law also recognizes another lawsuit for the protection of property rights. For example, if the inventory or illegal confiscation of property, you need to go to court with a claim for recognition of property rights, and its exclusion from the list, or the cancellation of an administrative act, not a norm property right.

Vindication and negatory claims can be given not only by the owners but also by owners of other property rights by all the legal entities-owners.

\section{Conclusion:-}

Thus, the absolute (real and legal) protection applies not only to the right of ownership and other real rights, but also to any legal possession. Substance and legal protection not only to the rightful owners, including the property of others, but also entities with the right binding, in fact, is the concept of the protection of ownership. Protection Institute of ownership is essential for civil appeals, in certain cases also protects honest possession. In addition, the person who is not an owner, but for a certain period of time honestly, openly and continuously owned as their own property (not having the owner's property, real estate), the right of ownership arises with respect to this property. The actual owner until the property rights can protect in its possession the property of any third parties who may qualify for it, by presenting real and legal action (with the exception of the person holding the right of ownership in respect of the property based on the law and the contract).

From our point, non-usage of claim period to the negatory lawsuit can be seen on followings:

Firstly, requirements (negatory claim) of the owner or another proprietor on elimination of any violations of their own rights, including offences, not connected to ownership, imposed only in respect of property situated in the immediate possession of the owner;

Secondly, the requirements of the owner in accordance to third parties, which are imposed on negatory claim, can be only as a part of the rights of use and disposal;

Third, the current Civil Code perpetuity of the property rights enshrined from the legal overlook (CC, art.164). The content of this provision is also rooted in the issue of non-usage of the claim period in accordance to negatory lawsuit of the owner. Because negatory claim is one of the methods of protection of ownership rights;

Lastly, another important aspect of non-usage of common claim period to the negatorny claims is that the owner has the right at any time to make a requirement on the prevention of illegal acts of third parties in respect to their rights and any offense and the protection of rights. Thus, since the establishment of a certain period in accordance to the protection of rights, the owner would face with certain artificial barriers in exercising their rights, and this; harm the development of social property relations, respectively.

Therefore, if the protection of property is connected to the right of ownership, arising under the contract, still it is an institute not of the right of obligation, real rights, and claim on its protection belongs to the category of materiallegal claims.

\section{References:-}

1. Constitution of the Republic of Uzbekistan. - Tashkent: Uzbekistan, 2015.

2. Ergashev V.Y. Actual problems of ownership rights and development prospective in the Republic of Uzbekistan. - Tashkent: TSIL, 2009. - P.203-204.

3. Civil law. Y.K.Tolstoy, A.P.Sergeev. - Moscow: Prospect, 1996. - P.399-400.

4. Zokirov I.B. Civil law of the Republic of Uzbekistan. - Tashkent: Adolat, 1996. - p.178.

5. Ergashev V.Y. Actual problems of ownership rights and development prospective in the Republic of Uzbekistan. - Tashkent: TSIL, 2009. - P.203-204.

6. Skryabin S.V. The ownership right in the Republic of Kazakhstan. - Almaty: 2000 - P.275.

7. Mengliev R.Sh. The protection of the right of ownership in civil law. - Dushanbe, 1999. - P.14. 